\title{
Women Entrepreneurship in Malaysia: an Investigation of the Factors that Motivated Micro and Small Business Owners in Kuching-Sarawak to Start-up their own Businesses
}

\author{
${ }^{1}$ Nwanesi Peter Karubi, ${ }^{2}$ Okpara Izuagba Uchenna, ${ }^{3}$ Anisiobi Anulika Loveline \\ ${ }^{1,2,3}$ Faculty of Social Sciences: University Malaysia Sarawak Malaysia
}

\begin{abstract}
This study examined the factors that motivated Malaysian women entrepreneurs, specifically those who operate in Kuching, Sarawak, to start-up their own businesses. However, the core focus of this study is on women entrepreneurs that are categorized as owners of 'micro and small enterprises (MSEs)'. Qualitative method was used to conduct this study. Thus, interview and observation were used to collect data from 31 respondents, and non-probability sampling method, specifically purposive sampling method, was used to select the respondents, due to inadequate information about them. The findings of this study showed that the respondents were motivated to start-up their own businesses by various extrinsic and intrinsic motivation factors. The major extrinsic motivation factors that encouraged them to start-up their own businesses are their 'low educational background' and 'the opportunity to manage their time by themselves'. On the other hand, the major intrinsic motivation factor that encouraged the respondents to start-up their own businesses is 'the opportunity for them to become their own boss'.
\end{abstract}

Keywords: Women Entrepreneurship, Micro and Small Business, Intrinsic and Extrinsic Motivation, and Opportunity and Necessity Entrepreneurs.

\section{Introduction}

Malaysian women account for almost half of the total population of the country ${ }^{1}$ (Gardena, 2012). Women-owned enterprises also account for $82,911^{2}$ of the total of 548,267 small and medium enterprises (SMEs) that operate in the three key economic sectors of Malaysia, which include; manufacturing, service, and agriculture (Shahid, 2010). In addition, women account for $47 \%$ of the total employment of the country's SMEs (Ibid.). Prior researches proved that women make significant contributions to the growth of Malaysia's economy by establishing unique businesses and developing outstanding products and services (see Ahmed, 2006 and Nauru, 2011). In spite of these, most of the entrepreneurship researches conducted in Malaysia is focused on men; very few researches have been done on women (Hafiz, 2011 and Musan, 2011).

In addition, prior researches showed that a good number of women entrepreneurs were motivated to start-up their own businesses due to lack of education, unemployment, and loss of spouse or parent ${ }^{3}$ (see Abdurrahman, 2004 and Kumar, 2005). Abdul (2006) also found that some of these women fail to operate their businesses successfully, because they were forced into entrepreneurship. In other words, they did not start their businesses willingly. ${ }^{4}$ On the other hand, Sani (2006) found that women entrepreneurs who were not forced into entrepreneurship $^{5}$ tend to be more successful, because they tend to dedicate more time and effort to their businesses. As a result, this study examined the factors that motivated Malaysian women entrepreneurs, specifically those who operate in Kuching, Sarawak, to start-up their own businesses. It also assessed the effects of these motivation factors on their businesses.

\section{Methodology}

Qualitative method was used to conduct this study. This method was chosen, because it provides researchers with the opportunity to ask more questions when necessary, thereby enabling them to gather a detailed and quality data. This is true, because the method enabled the researchers to ask the respondents more questions when they needed more information from them. This did not only help them to learn more about specific events concerning the respondents, it also helped them to gain insight into the respondents' interior

\footnotetext{
${ }^{1}$ That is to say, out of Malaysia's total population of 28.3 million, women account for 13.77 million or $47 \%$ of the population (Gardena, 2012).

${ }^{2}$ That is to say, women own $16 \%$ of the total of 548,267 SMEs in Malaysia (Shahid, 2010).

${ }^{3}$ This means that the women were extrinsically motivated to start-up their own businesses.

${ }^{4}$ They were extrinsically motivated to start-up their own businesses.

${ }^{5}$ This refers to women that were intrinsically motivated to start-up their own businesses.
} 
experiences, especially how they perceived and interpreted their perceptions, and how different events affected their thoughts and feelings (William, 2010). As a result of this, the researchers were able to understand the process of each event, instead of what just happened and how the respondents reacted to them.

The research instruments that were used to conduct this study are interview ${ }^{6}$ and observation. The greatest advantage of interview and observation is that they help to gather a detailed and quality data from the respondents (Marley, 2013). This is factual as the interviews and observations conducted while carrying out this study enabled the respondents to clearly explain themselves in detail and also provide other relevant social cues. Social cues, such as voice, intonation, and body language of the respondents provided the researchers with a lot of extra information that was added to their verbal answers. This level of detailed description (both verbal and non-verbal) showed a hidden interrelatedness between the emotions of the respondents and events.

The population of this study is mainly Sarawak women entrepreneurs. However, purposive sampling method was used to select a sample in Kuching, which represents the entire population. Purposive sampling method, which is a form of non-random sampling, was used to select 31 respondents for this study. The reason behind this is that there is inadequate information on the population of this study, which is specifically Kuching women entrepreneurs, who own micro and small businesses. Another reason is that purposive sampling reduces the amount of time necessary to search for appropriate respondents that meet the selection criteria required for the sample of a study (Sadan, 2011).

Additionally, most of the micro and small businesses owned by the women that this study is focused on are informal, because they are not formally registered with the Companies Commission of Malaysia $(\mathrm{CCM})^{7}$ (Companies Commission of Malaysia, 2014). As a result, there is no accurate record of the total number of these businesses (Ibid.).

The research area of this study is specifically Kuching. Kuching is the capital and most populous city in Sarawak. The total population of the city is 325,132 (Andrew, 2013). One of the reasons for choosing Kuching is that women constitute almost half of its population and almost all the ethnic groups in the country are well represented in the city. This facilitated easy access to the respondents of this study without exposing their identity to the public. Another reason for choosing Kuching is that it is the center of Sarawak's economic activities, and as such; there are many female entrepreneurs from diverse ethnic groups that are operating their businesses in the city. As a result of this, the researchers were able to collect a data that reflects the opinions and issues faced by women entrepreneurs from different ethnic groups in the state.

\section{Entrepreneurial Motivation Factors}

There are different motives that drive people to become entrepreneurs, these motives can be broadly categorized as intrinsic and extrinsic motivation factors (Ryan and Deci, 2010). To be motivated means to be encouraged to do something- a person who has no inspiration to act is thus characterized as unmotivated, whereas someone who is inspired to do something is considered motivated (Ibid.).

Intrinsic motivation is defined as the doing of an activity for its inherent satisfaction, rather than doing it for some external influence. For example, a woman who starts-up her own business, because of her need for achievement is considered intrinsically motivated to do so. This is because; she started the business willingly (i.e. there was no external pressure for her to do so). In contrast, extrinsic motivation is a behavior that takes place when one is being influenced to do something by an external force. For example, a woman who starts-up her own business, because of unemployment is considered extrinsically motivated to do so. This is because; she only started her own business, because she could not find a job. Thus, extrinsic motivation contrasts with intrinsic motivation, which refers to doing an activity simply for the enjoyment of the activity itself, rather than its instrumental value (Ibid.).

In the literature on the determinants of entrepreneurship, a distinction is often made between extrinsic and intrinsic motivation factors. An individual can either be extrinsically motivated into self-employment, because there was no other alternative, or can be intrinsically motivated into self-employment to pursue a business opportunity (Storey, 2004). Similarly, Thurrock (2007) argued that intrinsic factors refer to the expectation of being better off as an entrepreneur, while extrinsic factors are associated with an individual's level of dissatisfaction with their current employment. This means that "extrinsic and intrinsic motivation factors are comparable to necessity-based entrepreneurship and opportunity-based entrepreneurship,

\footnotetext{
${ }^{6}$ The interviews were conducted with the help of three local research assistants, who helped to translate the questions and responses from English Language to Bahasa Melayu and vice versa. This helped the respondents to clearly understand the questions they were asked before answering them. The research assistants were selected based on their strong command for both English Language and Bahasa Melayu, which is Malaysia's official language.

${ }^{7}$ The Companies Commission of Malaysia (CCM) is a statutory body formed under an Act of Parliament that regulates corporate and business affairs in Malaysia. It was formed in 2002 under the Companies Commission of Malaysia Act 2001, assuming the functions of the Registrar of Companies and Registry of Business. The main purpose of CCM is to serve as an agency to incorporate companies and register businesses as well as to provide company and business information to the public (Sheriff, 2013).
} 
respectively" (Bohla, 2006:23). Opportunity entrepreneurs (OE) are influenced by intrinsic factors to start a business, while necessity entrepreneurs (NE) are affected by extrinsic factors (ibid.).

The work of Rebronk (2002) supported the view that necessity entrepreneurs are not affected by the same factors as opportunity entrepreneurs. Rebronk argued that the motivation to become self-employed stems from the threat of unemployment or the discovery of an opportunity (Ibid.). Opportunity-based entrepreneurship involves those who choose to start their own business by taking advantage of an entrepreneurial opportunity; whereas, necessity entrepreneurs may never have considered starting or owning a business until there was no other option (Maritz, 2004). Maritz further argued that necessity-based entrepreneurship is most likely to occur when employment options are either absent or unsatisfactory (Ibid.).

Likewise, Maslow's (1954) hierarchy of needs explains necessity entrepreneurs as people that are extrinsically motivated to start their own businesses by the need to survive and provide shelter and food for themselves and their families. Whereas, opportunity entrepreneurs are people that are intrinsically motivated to start their own businesses by the need for achievement, self esteem, and self-actualization (Ibid.).

Recent studies have shown that the motivation to start a new business is far more complex for women than men, and that women tend to be more sensitive than men to a variety of non-monetary incentives (see Dallas, 2007 and Livinus, 2008). For example, for women more than for men, the motivation to start a new business is often linked to the type of independence that can accommodate family needs and child rearing (Ibid.).

In addition, Nieman (2008) presented a method for analyzing the 'why do women start businesses?' question by means of intrinsic and extrinsic motivation factors. The method focuses on the main factors that motivate women to become entrepreneurs. It is classified as either opportunity (i.e. intrinsic motivation factors) or necessity (i.e. extrinsic motivation factors) entrepreneurship. The method explains that a woman is extrinsically motivated to become an entrepreneur by factors like unemployment and job insecurity, while another is encouraged to become an entrepreneur by intrinsic motivation factors like need for achievement and recognition. Nieman further argued that business start-ups among women entrepreneurs are generally triggered by extrinsic and intrinsic motivation factors. Firstly, below are the extrinsic motivation factors highlighted by Nieman:

i. Unemployment: This refers to a person who does not have a job in the established economy.

ii. Job insecurity: For example, if a person is only appointed on a contract basis for a short-term period.

iii. Disagreement with the management: This may result from career limitations and setbacks in a conventional job.

iv. Inability to 'fit in' with the organization: This may be based on the inability to pursue a personal innovation in a conventional job.

v. The limitation of financial rewards from conventional jobs.

vi. Reaching the 'glass ceiling': This has to do with getting to a position where one is no longer getting promoted in an organization (Ibid.).

Secondly, the following are the intrinsic motivation factors highlighted by Nieman:

i. Independence: The freedom to work for oneself.

ii. Achievement: The sense of acknowledgement to be gained from running one's own venture.

iii. Recognition: A desire to gain the social standing achieved by entrepreneurs.

iv. Personal development: The freedom to pursue personal innovation.

v. Personal wealth: To gain the financial rewards of entrepreneurship (Ibid.).

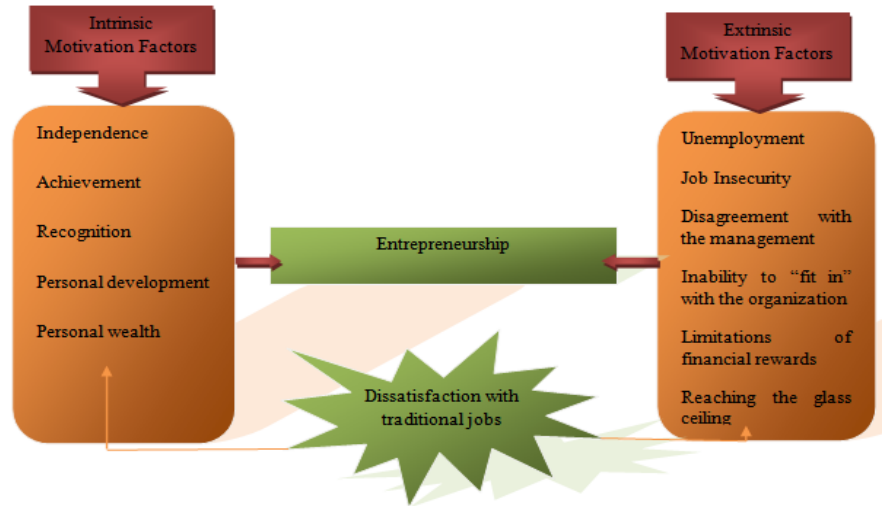

Source: "Intrinsic and Extrinsic Motivation Factors" (Nieman, 2008).

Figure 1: Intrinsic and extrinsic motivation factors 
Finally, the data from the field assisted in examining and describing the factors that motivates micro and small women entrepreneurs in Kuching, Sarawak to start their own businesses and how these factors affect the growth and sustainability of their businesses.

\section{Data Analysis}

This section contains the analysis of the demographic characteristics of the respondents. It also contains the analysis of the data gathered during the fieldwork based on the factors that motivated the respondents to start-up their own businesses and how these factors affect their businesses.

\subsection{Demographic Characteristics}

The age distribution of the respondents showed that most of them were between 36-40 years (35.5\%), followed by $16 \%$ who were between the ages of $46-50$. Also, about $16 \%$ of the respondents were between $41-45$ years, while $13 \%$ of them were between $31-35$ years. In addition, $13 \%$ of the respondents were between $26-30$ years, while $6.5 \%$ of them were between $20-25$ years.

The marital status distribution of the respondents showed that most of them are married; $84 \%$ of them are married, while $16 \%$ of them are single. This is similar to the findings of the study conducted by Teslim (2008), which showed that most women entrepreneurs are married, while few of them are single. This is probably because; most married women are able to get financial support from their husbands when starting their own businesses.

The findings of this study also showed that most of the respondents are Chinese. Chinese women entrepreneurs accounted for $61.3 \%$ of the respondents that took part in this study, while the Bidayuhs, Ibans, Malays, Indians, and other ethnic groups accounted for the remaining $38.7 \%$ of the respondents. This is consistent with the findings of Innocent (2012), which showed that the Chinese enjoy being independent, and as such; they tend to engage in entrepreneurship more than other ethnic groups in Malaysia.

The academic qualifications of the respondents were quite well distributed across six categories. The findings of this study showed that most of the respondents (61.3\%) only have primary education, while $16 \%$ of the respondents do not have any formal education. A similar trend was observed by Timothy (2007). In a study conducted in Malaysia, Timothy found that most women entrepreneurs, who own micro and small businesses, only have little formal education. Other respondents of this study have lower secondary education $(6.5 \%)$, higher secondary education (6.5\%), diploma education (6.5\%), and only $3.2 \%$ of the respondents have a degree.

Aside from their need to become independent, the low educational qualifications found among the respondents may be another reason why they chose to engage in entrepreneurship, rather than working for other organizations. Hafiz (2012) found that one of the major reasons why women start-up micro and small businesses is that they do not have enough educational qualification to get a good job.

\subsection{Factors that Motivated the Respondents to Start-up their Own Businesses}

As mentioned earlier, prior researches proved that entrepreneurs are motivated to start-up their own businesses either intrinsically or extrinsically (see Dawid, 2008 and Sanil, 2009). Being motivated intrinsically means that they were self motivated to start-up their own businesses, which could be as a result of their need for achievement or need for independence. In contrast, being motivated extrinsically means that they were forced to start-up their own businesses, which could be due to loss of spouse or parent, unemployment, urgent need for more money to sustain their families or dissatisfaction with their former workplace (Ibid.). Also, Lee (2010:57) argued that;

Entrepreneurs that are intrinsically motivated to start-up their own businesses are more likely to become successful than those that were extrinsically motivated to do so. This is because; they tend to be more committed, daring, innovative, and hardworking than the extrinsically motivated entrepreneurs.

As a result, the next discussion will be focused on examining various extrinsic and intrinsic motivation factors that encouraged the respondents to start-up their own businesses and how these factors affect their businesses.

\subsection{Extrinsic Motivation Factors}

The findings of this study showed that, out of the 31 respondents, 21 of them were extrinsically motivated to start-up their own businesses, while the remaining 10 were intrinsically motivated to do so. The findings also showed that all the extrinsically motivated respondents (21) were encouraged to start-up their own businesses as a result of their low educational background, while 16 of them were motivated to do so, because of both their low educational background and the opportunity to manage their time by themselves. ${ }^{8}$. In a nut shell,

\footnotetext{
${ }^{8}$ These respondents mentioned that, while working for other companies, they did not have enough time to carry out their family responsibilities and pursue their personal goals. This was because; they had to go and also come back from work at a particular time, else
} 
16 of the respondents were motivated to start-up their own businesses by two factors- low educational background and the opportunity for them to manage their time, while 21 of them were only motivated to start-up their own businesses, because of their low educational background.

When the respondents were asked why they mentioned low educational background as the major factor that motivated them to start-up their own businesses, most of them (15) stated that if they were educated up to first degree level, they would have preferred to get a good job, work for a while, save a reasonable amount of money, and start-up bigger businesses. These respondents further stated that they are still happy with their businesses, because it is better than the jobs they had before establishing their own businesses. Others (6) stated that if they were educated up to first degree level or more, they would have simply worked for big organizations and do their best to 'climb-up the corporate ladder', even to the point of becoming the key personnel of their organizations (e.g. managers and chief executive officers).

Likewise, when some of the 16 respondents that mentioned time management as another factor that motivated them to start-up their own businesses were asked the reason for their response, they mentioned that their business gives them the opportunity to manage their family responsibilities and personal goals. However, in order to have a clearer understanding of this factor, one of the respondents, Mrs. Julianne ${ }^{9}$, was asked why she mentioned 'time management' as her motivation factor, and she explained herself in detail. She said;

While working for my previous organization, I found it difficult to balance my family and work life. The reason was that I had to wake-up early in the morning on a daily basis to prepare dishes for my husband and kids, prepare and send my kids to school, and do other house chores before going to work. And I sometimes failed to wake-up on time because of tiredness. As a result, I tend to go to work a bit late, and this caused the organization I worked with to sometimes penalize me by deducting certain percentage from my salary, even though the salary was barely enough to sustain my needs and those of my family. This motivated me to start-up my own business as soon as I raised some money. It was not so difficult for me to save and start-up my own business because I sell vegetables and fruits. It only cost me RM1,200 to start-up the business, since I did not need to rent a shop. I only bought 2 tables, which I use to display my products, and a big umbrella, which I use to shield myself from the sun. Since I started my own business, I have succeeded in balancing my family and business life. As a result, my family is happier because I now dedicate more time to them.

\subsection{Intrinsic Motivation Factors}

The findings of this study showed that all the intrinsically motivated respondents (10) started their businesses, because they wanted to become their own boss. When the respondents were asked the reason for their response, the reasons they gave differ.

For instance, Mrs. Ajar, who owns a boutique, clearly explained why she mentioned 'being a boss' as the factor that motivated her to set-up her own business. She stated that;

As the owner of my business, I have the freedom to create my own schedule, although I sometimes work for longer hours than I anticipated, but I still have the flexibility to rearrange my operations to start later in the day, take some time-off, and prioritize my personal emergencies. I am happier now, because I could not do this when I was working for other companies.

Another respondent, Ms Edna, who owns a kindergarten school, also provided an elaborate explanation based on how the 'opportunity to become a boss' motivated her to start-up her own business. According to her; I am happy being my own boss, because it enables me to make all my decisions, nobody tells me what to do or how to do it. I do not have to report to anyone except for myself. I sometimes work overtime, but I can basically make my own hours and never get yelled at for being late. I can decide to work really hard one day and take half day off the next day. And being my own boss gives me a sense of satisfaction. I enjoy knowing that I started my own business by myself and am operating it successfully. Also, I never get worried about anyone firing me, because I have job security as long as I can continue to make my business run successfully. In contrast, while working for my previous organization, I always got worried about getting fired, due to cutbacks resulting from economic crises and/or poor organizational performance.

Additionally, Mrs. Fred, who owns a stationary store, narrated her reason for mentioning 'being a boss' as the factor that motivated her to set-up her own business. She said that;

I am happier now, because being a boss helps me to gain more income and accumulate wealth faster. For instance, I worked for 9 years, but I did not have much to show for it. However, being my own boss for only 4 years, I have successfully opened another outlet in a different location, because my business generates about 3 times more income than I used to make when working for my previous company. Though, as expected,

they will be penalized. However, since they started their own businesses, they have enjoyed the liberty of deciding when to go and come back from their business places without getting penalized by anyone.

${ }^{9}$ It is important to note that this is just a pseudo name. That is to say, it is not the real name of the respondent. This also applies to other names used to identify different respondents in this study. The reason for this is to protect the respondents from any form of problem that may arise if their real names were disclosed. 
it was a bit tough in my first year of operation, but I am a lot more successful now than when I was working. Moreover, being a boss enables me to take calculated risks and face challenges, which helps me to learn a lot and gain huge experiences. On the other hand, while working for my previous organization, it got to a point where I was no longer allocated challenging tasks, I kept on repeating similar tasks for many years. This did not only make my job very boring, it also prevented me from developing new skills, knowledge, and abilities.

Another respondent identified as Mrs. Daren, who owns a laundry business, also made the following remark as her reason for citing 'being a boss' as the motivation factor behind her business start-up. According to her;

There is no feeling better than one successfully achieving a goal and get to receive the whole selfsatisfaction without anyone coming along to claim the success as theirs. I am happier as a boss, because I am now in charge of setting my own goals and targets, deciding how and when they will be met, and judging my employees' performance. Setting out on my own has been highly challenging, but I feel very satisfied whenever I achieve my goals and targets. This makes me very happy.

Overall, the findings of this study showed that most of the respondents were extrinsically motivated to start-up their own businesses. This is consistent with the study conducted by Novas in 2004. Although Novas's study was carried out in France, his findings are similar to those of this study. According to Novas (2004:33); Women in micro and small business levels are either extrinsically or intrinsically motivated to start-up their own businesses. But, most of them are extrinsically motivated, while a few of them are intrinsically motivated to do so. Those that are extrinsically motivated usually start-up their own businesses mainly because of factors such as low educational background, and the need to manage their time. On the other hand, those that are intrinsically motivated usually start-up their own businesses, mainly because of one major factor, which is for them to become their own boss.

\section{Conclusion}

This study examined the factors that motivated Malaysian women entrepreneurs, specifically those who operate in Kuching, Sarawak, to start-up their own businesses. It also assessed the effects of these motivation factors on their businesses. The findings showed that most of the respondents (21) were motivated to start-up their own businesses by extrinsic motivation factors, while a few others (10) were intrinsically motivated to do so. The extrinsic motivation factors that encouraged the respondents to start-up their own businesses include 'their low educational background and time management', while the intrinsic motivation factor that encouraged them to start-up their own businesses is their 'desire to become their own boss'.

This study uncovered the fact that multiple relationships exist between the underlying facets of motivational factors and women's need to start-up micro and small businesses. This supports the various arguments presented in the earlier part of this study (see Ryan and Deci 2010; Storey 2004 and Thurrock 2007). Therefore, this study discovered that the understanding of the motivational factors that encourage women to go into business may help in predicting the nature of their businesses, kinds of challenges they face, and the necessary steps needed to address their growth and sustainability issues. Moreover, based on the findings of this study and the literature reviewed, the following recommendations are made to encourage and promote women entrepreneurship in Kuching, Sarawak:

1. Women entrepreneurs should ensure that they join or build a business network that will connect them together, so that they can help each other in various ways. Networking is a powerful tool by which entrepreneurs use a wide variety of contacts to help them achieve their business and professional objectives (Borges, 2012). It gives them greater access to information, new clients, and people with similar business interests. A lot of women entrepreneurs are used to being self-reliant when it comes to meeting their own needs. They have to learn that their business objectives can often be met more effectively and efficiently through collaboration with others (Ibid.). In addition, micro and small enterprise (MSE) support agencies and training providers should help to establish a habit of networking by setting-up and facilitating networks for women entrepreneurs. These would provide an appropriate environment in which women can develop their networking skills before joining established business networks and organizations.

2. Government should create strong informal associations, especially for women entrepreneurs who operate in the informal sectors. There are a number of associations for women-owned micro and small enterprises in the country; however, with the exception of the formal organizations of formal small and medium size enterprises, the capacity of many of the informal associations is weak (Bala, 2013). Strengthening the existing associations and supporting female micro and small entrepreneurs to organize themselves can help to enhance their capacity to express their common interests and advocate for improved policy environment and increased investment in the various subsectors in which they operate. 
3. Lack of statistical data on informal businesses is a major problem for researchers, policy formulation, and program development. Gender statistics on the characteristics and business practices of female and male entrepreneurs are necessary for informed decision making and researches. Government statistical offices and their partners, such as the Companies Commission of Malaysia (CCM), are key players in collecting, analyzing, and disseminating key information to the government, researchers, and the general public. Therefore, it is recommended that attention be paid to collect sufficient and detailed gender statistics on the country's micro and small enterprises. This would help the government to develop policies that would equally favour the male and female entrepreneurs in the country. It would also help researchers to easily access lots of information about women entrepreneurs who operate in both the formal and informal sectors, thereby selecting their research samples randomly. This, in turn, would enable them to easily generalize their findings.

\section{References}

[1] Maslow, (1954), "Hierarchy of Needs in Relation to Necessity and Opportunity Entrepreneurs," Journal of Management, Vol. 18. Pp. 13-14.

[2] Timothy, (2007), Education Levels of Women Entrepreneurs, Journal of Social Sciences, Vol. 4. Pp. 15.

[3] Companies Commission of Malaysia (CCM), (2014), "Enquiry About Women-Owned Micro and Small Businesses," Obtained in February 24th 2014

[4] Andrew, (2013), Background of Kuching City, Journal of International Business, Vol. 7. Pp. 9

[5] Rebronk, (2002), Intrinsic and Extrinsic Motivation Factors in Relation to Opportunity and Necessity Entrepreneurs, Journal of Management, Vol. 6. Pp. 4-7.

[6] Teslim, (2008), Married and Single Women Entrepreneurs: A Comparative Study, Journal of Social Sciences, Vol. 5. Pp. 3

[7] Sadan, (2011), Purposive Sampling Method, Journal of Research Sampling Method, Vol. 3. Pp. 45-58

[8] E. Sanil, (2009), Entrepreneurship and Economic Growth, Journal of Economics, Vol. 24. Pp. 56-76.

[9] E. Shahid, (2010), Entrepreneurial Growth, Journal of Business Development, Vol. 3. Pp. 2-13.

[10] Ahmed, (2006), How Women Contribute to the Country's Economic Growth, Journal of Entrepreneurship, Vol. 12. Pp. 7-17.

[11] Dallas, (2007), Entrepreneurial Motivation Factors, Journal of Entrepreneurship, Vol. 4. Pp. 45-47

[12] G. Kumar, (2005), Challenges of an Entrepreneur, Journal of Entrepreneurship, Vol. 7. Pp. 3-18.

[13] G. Ryan, and M. Deci, (2010), Intrinsic and Extrinsic Motivation Factors, Journal of Business Management, Vol. 5. Pp. 11-13.

[14] Musan, (2011), Women Entrepreneurship, Journal of Management, Vol. 3. Pp. 19-36.

[15] H. Nauru, (2011), How Women Contribute to the Country's Economic Growth, Journal of Entrepreneurship, Vol. 8. Pp. 5-8.

[16] Storey, (2004), Intrinsic and Extrinsic Motivation Factors, Journal of Management, Vol. 23. Pp. 12-14.

[17] Marley, (2013), The Greatest Advantages of Interview, Journal of Social Sciences, Vol. 6. Pp. 23-24.

[18] Innocent, (2012), The Chinese and Their Entrepreneurial Characteristics, Journal of Entrepreneurship, Vol. 5. Pp. 16.

[19] Nieman, (2008), Intrinsic and Extrinsic Motivation Factors, Journal of Entrepreneurship, Vol. 4. Pp. 51-58.

[20] L. Thurrock, (2007), Intrinsic and Extrinsic Motivation Factors in Relation to Opportunity and Necessity Entrepreneurs, Journal of Entrepreneurship, Vol. 7. Pp. 45-48.

[21] L. William, (2010), Benefits of Qualitative Research Approach, Journal of Social Sciences, Vol. 10. Pp. 89-90.

[22] Hafiz, (2012), Women's Motivation for Starting their Own Businesses, Journal of Entrepreneurial Motivation Factors, Vol. 6. Pp. 4.

[23] M. Abdul, (2006), Issues of Entrepreneurship, Journal of Entrepreneurship, Vol. 17. Pp. 67-101.

[24] M. Hafiz, (2011), How Women Entrepreneurs Contribute to Malaysia's Economic Growth, Journal of Entrepreneurship, Vol. 3. Pp. 5-7.

[25] M. Lee, (2010), Entrepreneurship: Motivation Factors and Business Growth, Journal of Economics, Vol. 12. Pp. 57-89.

[26] Sani, (2006), Challenges of Women Entrepreneurs, Journal of Entrepreneurship, Vol. 19. Pp. 71-120.

[27] R. Abdurrahman, (2004), Problems Faced by Entrepreneurs, Journal of Entrepreneurship, Vol.12. Pp. 5-19.

[28] R. Bohla, (2006), Intrinsic and Extrinsic Motivation Factors in Relation to Opportunity and Necessity Entrepreneurs, Journal of Entrepreneurship, Vol. 17. Pp. 23-26.

[29] R. Dawid, (2008), Entrepreneurship and Business Venture, Journal of Management, Vol. 23. Pp. 45-79

[30] R. Gardena, (2012), Entrepreneurship and Economic Development, Journal of Management, Vol. 5. Pp. 12-13.

[31] R. Livinus, (2008), Entrepreneurial Motivation Factors, Journal of Entrepreneurship, Vol. 4. Pp. 15-18.

[32] U. Sheriff, (2013), The Companies Commission of Malaysia (CCM), (Kuala Lumpur, Malaysia, Hafiz Publishing),

[33] W. Bala, (2013), Importance of Creating Strong Informal Associations for Women Entrepreneurs, Journal of Entrepreneurship, Vol. 5. Pp. $12-14$

[34] W. Borges, (2012), Importance of Networking Among Women Entrepreneurs, Journal of Entrepreneurship, Vol. 3. Pp. 12-13

[35] W. Maritz, (2004), Intrinsic and Extrinsic Motivation Factors in Relation to Opportunity and Necessity Entrepreneurs, Journal of Management, Vol. 5. Pp. 56-59.

[36] Z. Novas, (2004), Women's Entrepreneurial Motivation Factors, Journal of Entrepreneurship, Vol. 3. Pp. 19-23. 